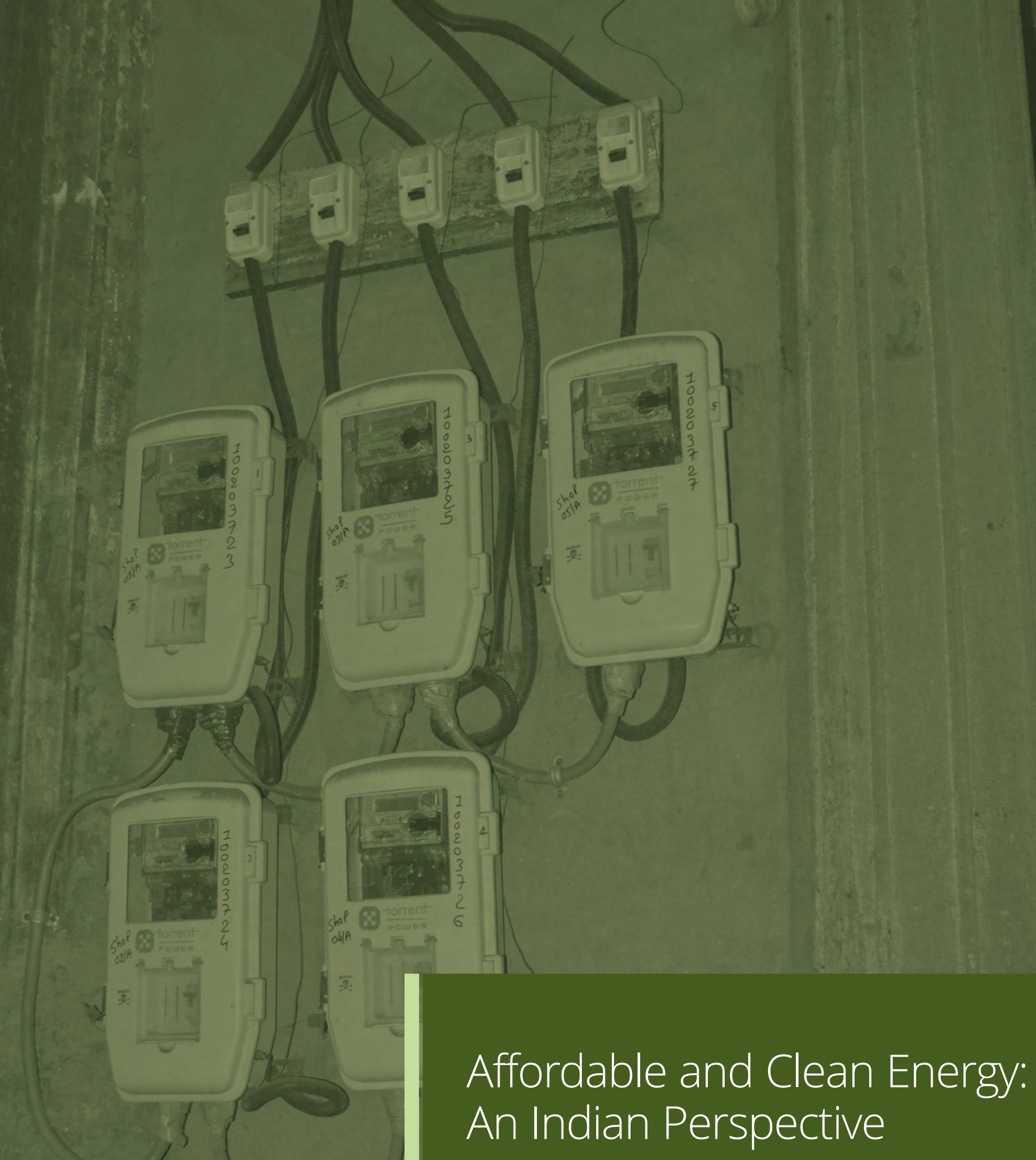

Kenrick Mascarenhas, Ritwika Basu \& Amir Bazaz 



\section{Sustainable Development Goal 7: Affordable and Clean Energy}

\section{Background}

Energy and its availability defines the majority of the challenges and opportunities that civilisation faces today. Access to energy for all is essential as everyday lives depend on reliable and affordable energy services, considered as a precursor to improved quality of life and equitable development. It is widely recognised that modern energy services are crucial to human well-being, is vital for any country's economic development and is essential for the provision of clean water, sanitation, health care and for other useful energy services. Achieving universal sustainable energy provision is an opportunity that has the potential to transform lives and economies.

In order to contextualise the discussion on SDG Goal 7, it might be useful to understand the specific targets (to be achieved by 2030), which are identified below. This is essential to understand the broad framework of intervention within which efforts towards achieving the various targets is embedded.

- Ensure universal access of affordable, reliable and modern energy services;

- Increase substantially the share of renewable energy in the global energy mix;

- Double the global rate of improvement in energy efficiency;

- Enhance international cooperation to facilitate access to clean energy research and technology, including renewable energy, energy efficiency and advanced and cleaner fossilfuel technology, and promote investment in energy infrastructure and clean energy technology;

- Expand infrastructure and upgrade technology for supplying modern and sustainable energy services for all.

When we read between the lines, we understand that the entire SDG framework of Goal 7 (UN, 2015) emphasises certain key issues, which form the basis of understanding the practicality of triggering energy transitions that has the potential to transform lives and economies. These issues are broadly categorised around energy access challenges; improving affordability and reliability of modern energy services; enhancing the quantum of renewable energy in the primary energy mix; improving technology penetration and exchange, particularly with regards to access to clean energy research; and finally, focussing on improving energy efficiency across the entire energy value chain. 


\section{Introduction to the Energy Sector in India}

\section{Issues and Challenges}

Economic activity in India during the 1990s and 2000s, has undergone enormous growth and transition from an agrarian to an industrial and service sector economy, transforming the energy needs of the country. This has resulted in two significant patterns: energy demand always outstripping supply, and intensification of energy input per unit economic output of the economy. The imperatives of economic growth, considered necessary to eliminate widespread poverty and achieve real income growth, require energy in multiple forms and at affordable prices. As a country, we are still collectively struggling to gain access to different useful forms of energy while also keeping the prices low, without the presence of hugely distorting subsidies. Although there has been a significant decoupling of energy and economic growth in the past few decades pointing towards enhanced efficiency gains, a large section of the population is still deprived of access to energy.

In addition, there is still an enormous dependence on imported energy (oil, in particular). Such an external dependence raises questions around India's long-term energy security.1 Further, the rate of diffusion and deployment of emerging new renewable energy technologies has been slow. Poor public health outcomes persist owing to the extraction and use of fossilenergy and the resulting human exposure to local air pollutants and increased human exposure to indoor air pollutants due to a higher use of biomass for residential energy use. Poor health outcomes are also observed due to the accumulation of black carbon in the atmosphere, primarily due to inefficient energy conversion processes on the end-use side. It is reasonably recognised that meeting the basic needs of access to sustainable energy to the millions of Indians while at the same time addressing and responding to global and national climate goals is going to be a key energy policy challenge in the recent future. There is a wide convergence on the principal steps before the Indian energy sector, in line with achieving the broader agenda highlighted above. These include enhancing energy supply and improving energy security, focussing on policies and programmes that help reduce economy-wide energy intensity, pricing reasonably to help transition from a fossil-based economy to a cleaner national energy profile, and ensuring maximum gains are achieved through energy efficiency improvements by a mix of responses: technology, behavior and price.

It is needless to highlight that we lack an alternative, competitive energy resource to coal. India's incumbent energy structure is heavily fossil-dependent, primarily driven by coal and oil. It is widely accepted that the heavy fossil structure of the Indian energy sector will remain reasonably high in the next 2-3 decades. It must also be reiterated that most of the coal use is for electricity production by an inefficient stock of power plants and a very high percentage of oil is used to satisfy the energy guzzling transport sector, which is one of the fastest growing energy intensive sectors in India. 
India's energy demand since 2000 has almost doubled, pushing up the country's share in global demand to 5.7 per cent in 2013 from 4.4 per cent at the beginning of the century as reported by the India Energy Outlook report (IEA, 2015). While the energy demand growth which drives economic growth has been substantial, this proportion is still well below India's near 18 per cent current share of global population, a strong indicator of the potential for further growth. On observing some of the most common energy indicators (see Table 1), we see that energy demand, in line with the economic growth targets, are bound to increase substantially. Even reaching the lower edge of the global standard measures means a lot of energy demand and supply imperative, a significant public policy challenge for India.

Table 1: Energy indicators for India and other regions

\begin{tabular}{|c|c|c|c|c|}
\hline Country & $\begin{array}{l}\text { Electricity } \\
\text { consumption } \\
\text { [MWh/capita] }\end{array}$ & $\begin{array}{l}\text { TPES per } \\
\text { capita } \\
\text { [toe/capita] }\end{array}$ & $\begin{array}{l}\text { TPES per GDP } \\
\text { (2005 prices) } \\
\text { [toe/1000 USD] }\end{array}$ & $\begin{array}{l}\text { GDP per } \\
\text { capita } \\
\text { [GDP/capita] }\end{array}$ \\
\hline USA & 12.99 & 6.92 & 0.15 & 45.66 \\
\hline European Union & 6.03 & 3.2 & 0.11 & 29.79 \\
\hline World Average & 3.03 & 1.9 & 0.24 & 7.94 \\
\hline China & 3.77 & 2.21 & 0.62 & 3.58 \\
\hline Southeast Asia & 0.92 & 0.71 & 0.44 & 1.60 \\
\hline Africa & 0.58 & 0.67 & 0.53 & 1.27 \\
\hline India & 0.78 & 0.62 & 0.52 & 1.19 \\
\hline
\end{tabular}

Source: IEA, 2015

Figure 1: Per capita energy consumption in India and other regions

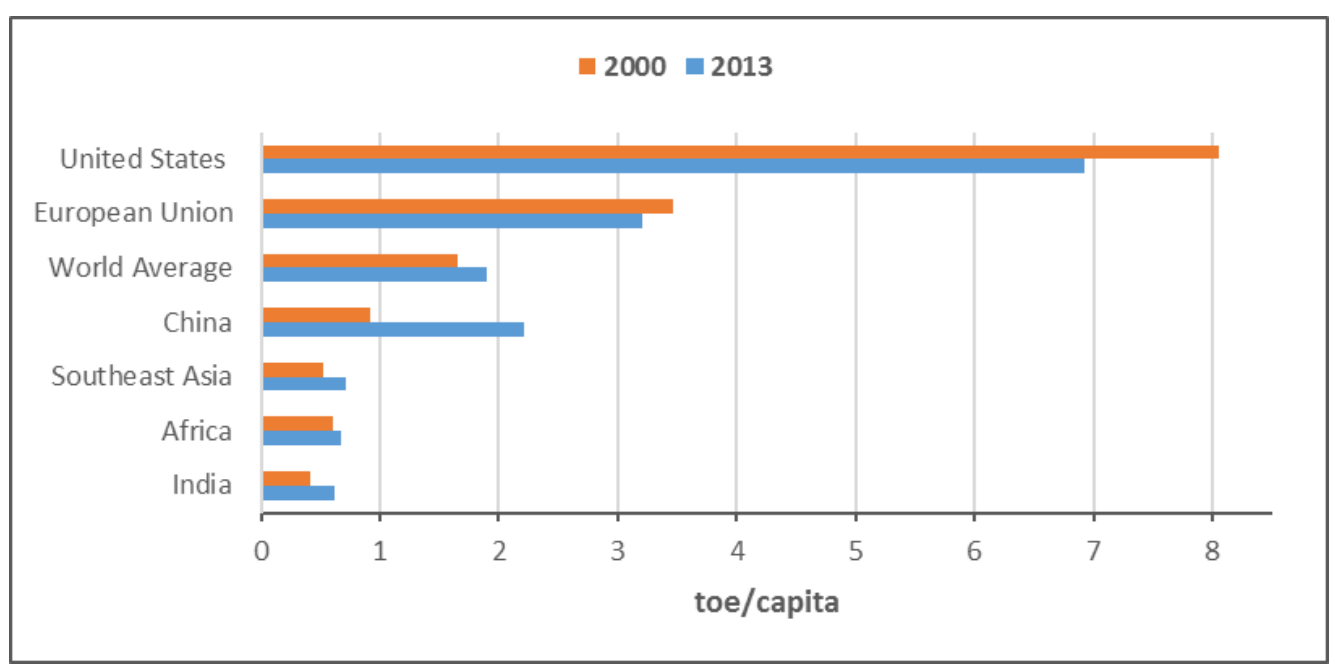

Source: IEA, 2015

Expressed on a per capita basis, energy demand in India has grown by 46 per cent since 2000 and remains only around one third of the global average (see Figure 1). Even though energy demand has almost doubled since 2000, we observe a higher rate of energy-economy decoupling. This is partly due to a higher penetration of modern energy in the residential sector, high energy consumption benchmarks in the rising service sector and dedicated public 
policy for improving end-use energy efficiency. India's energy intensity 2 has been declining over the years and it is expected to decline further (see Figure 2).

Figure 2: Total primary energy supply and GDP

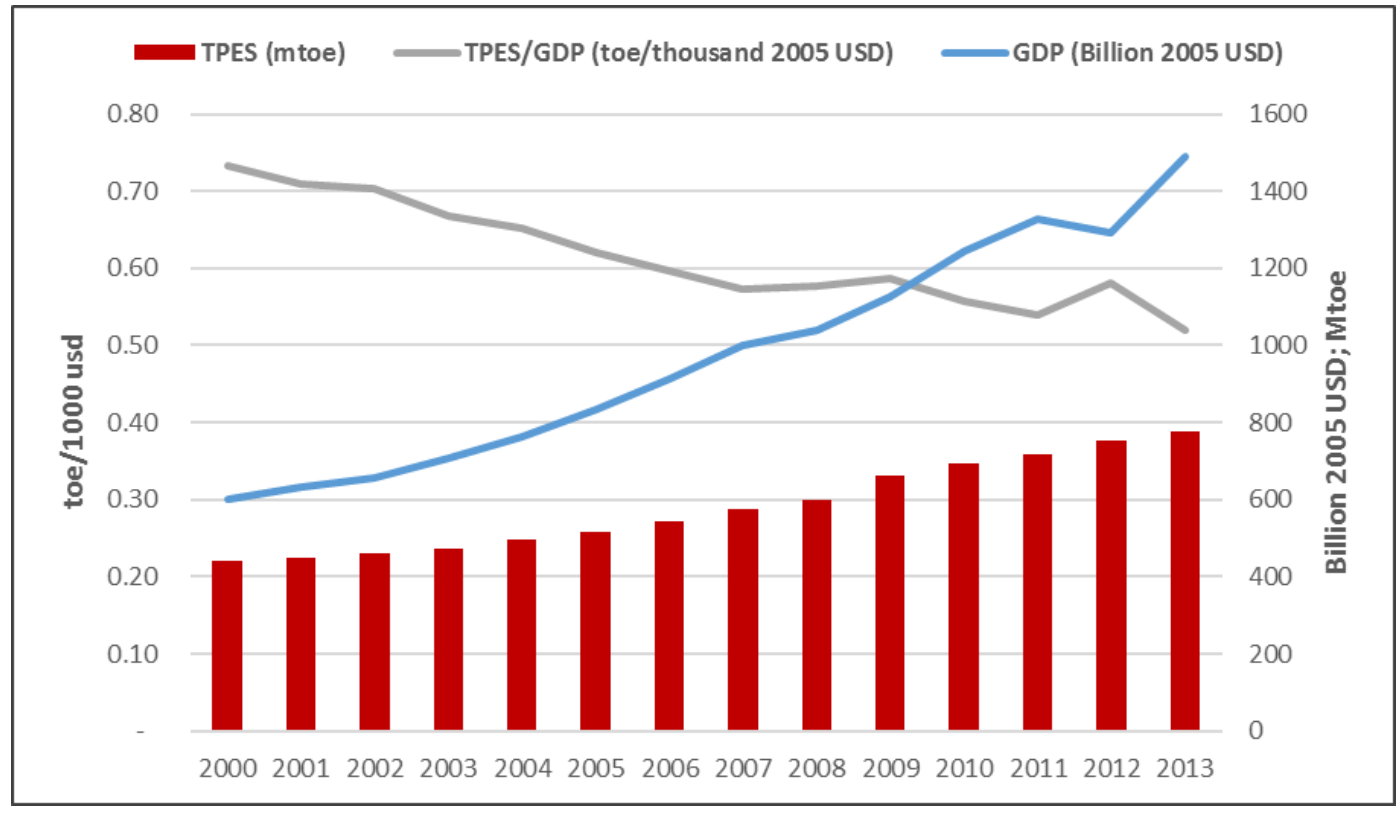

Source: IEA, 2015

India's 12th FYP (GOI, 2013) underlines the dependence on costly energy imports, emphasises the development of a policy that allows extraction of all available domestic energy resources and ensures that energy prices are affordable and thus, non-exclusionary. In line with the broader principles within which India's energy sector challenges are to be tackled, the 12th FYP emphasised the importance of using the framework of low-carbon development so as to mainstream cleaner forms of energy without compromising on economic growth targets. This approach has broadly shaped the energy sector strategy.

\section{Policies and Programmes in the Energy Sector}

\section{An Overview}

Government response in the energy sector has been very active, particularly in the last twothree decades. Most of these responses have been in the realm of correcting the energy market through use of 'hard' and 'soft' policy measures. The dominant objective that helps drive the energy sector programme and policy landscape is centred on providing costeffective energy supply. It must be recognised that most of the economic gains (or cost effectiveness) have been largely realised in the demand sector. The energy supply sector is largely plagued with poor quality energy infrastructure. It is commendable to observe many 
market- and non-market- based innovations that have taken root in the Indian energy policy domain. It is also reasonably important to understand that most of these innovations have regulatory foundations that enabled changing the transaction rules, in addition to a liberal perspective taken by the Government of India in the technology market.

It has also been increasingly emphasised per the Integrated Energy Policy (GOI, 2006) that emerging market-based interventions provide the best possible option in the context of energy supply/demand challenges. Some of the interventions that have found favour with policy makers include promoting competitive energy markets, pricing appropriately, allocating resources efficiently (through regulation), improving efficiency, and introducing management reforms that create a mechanism to implement efficiency improvements and promote accountability. Whether this is the best way forward is something that needs deeper analysis and reflection. It is important to recognise that the energy sector is characterised by many stakeholders and a contestable state-centre relationship.

There have been numerous policy initiatives, legislations and acts enacted and introduced over the last few decades. While some directly concern the energy sector, others have indirectly influenced developments in the sector. These policies, legislations and acts have focussed either individually on an environmental sector like water or air, or they have broadly targeted the entire value chain of the energy sector. For example, the latest policy document adopted by the Government of India is the Integrated Energy Policy roadmap (GOI, 2006). This policy roadmap was accepted by the Government of India (GOI) in 2009, and it broadly links the energy sector to the goals of sustainable development. The IEP laid down the foundation to secure the country's fuel demand with respect to different substitutable fuels in both production and alternative technologies to exploit possible synergies between production and consumption. Details of some of the key programmes/policies and measures to promote energy efficiency in India are shared in Table 2 below.

Table 2: Key Energy Policies and Legal Measures, Acts

\begin{tabular}{|c|c|c|}
\hline Policy & Objectives & Features \\
\hline \multirow{2}{*}{$\begin{array}{l}\text { National Road } \\
\text { Transport } \\
\text { Policy, Central } \\
\text { Road Fund Act } \\
\text { (2000) }\end{array}$} & $\begin{array}{l}\text { To promote modern, energy } \\
\text { efficient and environment friendly } \\
\text { road transport. }\end{array}$ & $\begin{array}{l}\text { Central Road Fund through collection of } \\
\text { cess from petrol and diesel. }\end{array}$ \\
\hline & $\begin{array}{l}\text { Promote public transport, create } \\
\text { better roads, and upgrade State } \\
\text { Road Transport Corporations. }\end{array}$ & $\begin{array}{l}\text { Cess of Rs } 2 / \text { litre is collected on petrol and } \\
\text { high speed diesel oil. }\end{array}$ \\
\hline \multirow[t]{3}{*}{$\begin{array}{l}\text { Energy } \\
\text { Conservation } \\
\text { Act (2001) }\end{array}$} & \multirow{3}{*}{$\begin{array}{l}\text { Empower the Central and State } \\
\text { Governments (in some instances) to } \\
\text { enhance energy efficiency (energy } \\
\text { consumption standards and norms } \\
\text { for end use sectors and consumers, } \\
\text { energy audits) and } \\
\text { establish Bureau of Energy } \\
\text { Efficiency to reduce energy intensity } \\
\text { in the Indian economy. }\end{array}$} & $\begin{array}{l}\text { Bureau of Energy Efficiency (BEE) set up to } \\
\text { specify Standards and Codes (S\&C) for } \\
\text { equipment used in industries. }\end{array}$ \\
\hline & & $\begin{array}{l}\text { Improvement in Energy Efficiency through } \\
\text { capacity building and energy audits. }\end{array}$ \\
\hline & & $\begin{array}{l}\text { Accelerated and sustained adoption of } \\
\text { energy efficiency in all sectors of the } \\
\text { economy. }\end{array}$ \\
\hline
\end{tabular}




\begin{tabular}{|c|c|c|}
\hline \multirow[t]{2}{*}{$\begin{array}{l}\text { Electricity Act } \\
\text { (2003) }\end{array}$} & $\begin{array}{l}\text { Encourage autonomous regulation } \\
\text { with the separation of policy and } \\
\text { operational aspects. }\end{array}$ & $\begin{array}{l}\text { Consolidates laws relating to generation, } \\
\text { transmission, distribution, trading and use } \\
\text { of electricity }\end{array}$ \\
\hline & $\begin{array}{l}\text { Rationalise tariff and lower the } \\
\text { cross-subsidisation levels; Create } \\
\text { competition in the industry; Ensure } \\
\text { supply of electricity to all areas; } \\
\text { Protect consumer interests. }\end{array}$ & $\begin{array}{l}\text { Rationalisation of electricity tariff and } \\
\text { policies related to subsidies. }\end{array}$ \\
\hline \multirow[t]{4}{*}{$\begin{array}{l}\text { Tariff Policy } \\
\text { (2006) }\end{array}$} & $\begin{array}{l}\text { Ensure availability of electricity to } \\
\text { consumers at reasonable and } \\
\text { competitive rates. }\end{array}$ & $\begin{array}{l}\text { Provisions regarding renewable energy and } \\
\text { co-generation. }\end{array}$ \\
\hline & $\begin{array}{l}\text { Ensure financial viability of the } \\
\text { sector and attract investments. }\end{array}$ & $\begin{array}{l}\text { Fixed minimum percentage for purchase of } \\
\text { energy from renewable sources, taking into } \\
\text { account resource availability and impact on } \\
\text { tariffs. }\end{array}$ \\
\hline & $\begin{array}{l}\text { Promote transparency, consistency } \\
\text { and predictability in regulatory } \\
\text { approaches across jurisdictions and } \\
\text { minimise perceptions of regulatory } \\
\text { risks. }\end{array}$ & \multirow[t]{2}{*}{$\begin{array}{l}\text { Procurement by distribution companies to } \\
\text { be done at preferential tariffs to encourage } \\
\text { non-conventional energy technologies } \\
\text { through a competitive bidding process. }\end{array}$} \\
\hline & $\begin{array}{l}\text { Promote competition, efficiency in } \\
\text { operations and improvement in } \\
\text { quality of supply. }\end{array}$ & \\
\hline \multirow{4}{*}{$\begin{array}{l}\text { Integrated } \\
\text { Energy Policy } \\
\text { (2006) }\end{array}$} & \multirow{2}{*}{$\begin{array}{l}\text { To reliably meet demand for energy } \\
\text { services of all sectoral energy needs } \\
\text { (including vulnerable households). }\end{array}$} & $\begin{array}{l}\text { Promote energy-efficiency by enforcing } \\
\text { energy standards effectively. }\end{array}$ \\
\hline & & $\begin{array}{l}\text { Provide appropriate fiscal policies to take } \\
\text { care of negative externalities, and } \\
\text { independent regulation to take care of anti- } \\
\text { competitive market behavior. }\end{array}$ \\
\hline & \multirow{2}{*}{$\begin{array}{l}\text { Provide safe and convenient energy } \\
\text { at the lowest cost in a technically } \\
\text { efficient, economically viable, and } \\
\text { environmentally sustainable } \\
\text { manner to ensure India's energy } \\
\text { security. }\end{array}$} & $\begin{array}{l}\text { Actively promote technologies that } \\
\text { maximise energy efficiency, demand side } \\
\text { management, conservation and energy } \\
\text { security. }\end{array}$ \\
\hline & & $\begin{array}{l}\text { Encouraging domestic research into such } \\
\text { technologies and free access to suitable } \\
\text { energy-related technologies available } \\
\text { abroad. }\end{array}$ \\
\hline $\begin{array}{l}\text { National Energy } \\
\text { Labelling } \\
\text { Programme } \\
\text { (2006) }\end{array}$ & $\begin{array}{l}\text { The objectives of Standards \& } \\
\text { Labelling programme is to provide } \\
\text { the consumer an informed choice } \\
\text { about energy saving and thereby } \\
\text { the cost saving potential of the } \\
\text { marketed household and other } \\
\text { equipment. }\end{array}$ & $\begin{array}{l}\text { Expected to impact energy savings in the } \\
\text { medium and long term while at the same } \\
\text { time position the domestic industry to } \\
\text { compete in such markets where norms for } \\
\text { energy efficiency are mandatory. }\end{array}$ \\
\hline \multirow[t]{2}{*}{$\begin{array}{l}\text { National Policy } \\
\text { on Biofuels } \\
\text { (2009) }\end{array}$} & \multirow{2}{*}{$\begin{array}{l}\text { Mainstream biofuels and, therefore, } \\
\text { envision a central role for it in the } \\
\text { energy and transportation sectors } \\
\text { of the country in the coming } \\
\text { decades. }\end{array}$} & $\begin{array}{l}\text { An indicative target of } 20 \% \text { blending of } \\
\text { biofuels both for biodiesel and bioethanol } \\
\text { by } 2017 \text {. }\end{array}$ \\
\hline & & $\begin{array}{l}\text { Encourage biodiesel production from non- } \\
\text { edible oilseeds on waste, degraded and } \\
\text { marginal lands. }\end{array}$ \\
\hline
\end{tabular}




\begin{tabular}{|c|c|c|}
\hline & & $\begin{array}{l}\text { A Minimum Support Price (MSP) for farmers } \\
\text { producing non-edible oilseeds for biodiesel } \\
\text { production. }\end{array}$ \\
\hline & & $\begin{array}{l}\text { Financial incentives for new and second } \\
\text { generation biofuels, including a National } \\
\text { Biofuel Fund. }\end{array}$ \\
\hline $\begin{array}{l}\text { Demand Side } \\
\text { Management } \\
\text { (2009) }\end{array}$ & $\begin{array}{l}\text { The objective is to create models to } \\
\text { identify energy efficiency } \\
\text { improvement projects and } \\
\text { implement strategies for energy } \\
\text { management. }\end{array}$ & $\begin{array}{l}\text { The goal of energy management must be } \\
\text { provision of energy with the least social } \\
\text { cost. }\end{array}$ \\
\hline $\begin{array}{l}\text { National Clean } \\
\text { Energy Fund } \\
\text { (2011) }\end{array}$ & $\begin{array}{l}\text { As per the NCEF guidelines, the fund } \\
\text { has been established to 'fund } \\
\text { research and innovative projects in } \\
\text { clean energy technologies.' }\end{array}$ & $\begin{array}{l}\text { The cess on coal which feeds the NCEF has } \\
\text { been increased from } \square 50 \text { to } \square 100 \text { per } \\
\text { tonne in budget } 2014-15\end{array}$ \\
\hline $\begin{array}{l}\text { Twelfth Five } \\
\text { Year Plan } \\
\text { (2012-2017) }\end{array}$ & $\begin{array}{l}\text { Promote 'faster, sustainable and } \\
\text { more inclusive growth'; reduce } \\
\text { emission intensity of GDP by } 20- \\
25 \% \text { over } 2005 \text { levels; add } 30,000 \\
\text { MW of renewable energy capacity. }\end{array}$ & $\begin{array}{l}\text { Develop and adopt low carbon strategy for } \\
\text { inclusive growth in order to improve the } \\
\text { sustainability of its growth process; focus } \\
\text { on the major carbon emitting sectors such } \\
\text { as power, transport, industry, buildings and } \\
\text { forestry. }\end{array}$ \\
\hline $\begin{array}{l}\text { National } \\
\text { Renewable } \\
\text { Energy Law } \\
2015 \text { (Draft) }\end{array}$ & $\begin{array}{l}\text { Create legislative framework for } \\
\text { further deployment of renewable } \\
\text { energy in India. }\end{array}$ & $\begin{array}{l}\text { The draft of the law covers the following } \\
\text { issues: security payments, renewable } \\
\text { energy fund, grid access and decentralised } \\
\text { energy. }\end{array}$ \\
\hline
\end{tabular}

It is to be reiterated that technology and its availability has always been an important energy policy driver in the Indian context. The public policy orientation has therefore been skewed towards accessing, deploying and disseminating energy technologies that help in maximising energy supply options, enable demand side management/transition3 and achieve goals of reasonable energy conservation.

Demand Side Management (DSM) options are being aggressively pursued to reduce demand for electricity (and therefore for coal) through widespread uptake of energy efficient processes, equipment, lighting and buildings. Some of the DSM measures that are being implemented/planned include allowing utilities to factor DSM expenditure into tariff plans; setting up of a DSM cell by every energy supply company/utility which is guided and facilitated by the Bureau of Energy Efficiency; implementing Time-of-Day (TOD) tariffs for large industrial and commercial consumers to flatten the load curve; improving efficiency of industrial, municipal and agricultural water pumping systems to encourage adoption of efficient pumping systems and shifting of pumping load to off-peak hours; promoting solar hot-water systems and undertaking large-scale implementation of efficient lightning initiatives. 


\section{Reframing the 'Energy' Agenda}

\section{Climate Mitigation Agenda is Important to Re-design the Energy Sector and its Functioning}

There is a reasonable amount of decoupling between economic growth, energy and carbon emissions (see Table 3 for an overview of some of the interventions that have allowed for energy and carbon decoupling). While examining the nature of energy and carbon decoupling, we observe that the rate of carbon decoupling has been relatively more in comparison to energy decoupling. This may be partly explained by the low-base of carbon emissions and very high coverage of the country's population by non-commercial biomass. On the contrary, we are not sure at this moment that the energy and carbon decoupling is happening in a conjoint manner. Evidently, there are significant gains in designing, implementing and managing conjoint emission-energy pathways, requiring a serious re-think of the operational functionality of the conjoint market. However, the national policy response is geared more towards achieving energy efficiency gains without utilising the possibility of achieving climate gains too. This has emerged as a serious flaw that may create impediments towards reframing the energy sector agenda.

An energy and carbon decomposition analysis for the country reveals interesting findings. Overall, the Indian emissions trajectory is primarily being driven by income growth, a strongly correlated factor with urbanisation and the levels of economic growth. This trajectory is influenced more by the energy intensity of GDP and less by carbon intensity drivers. In the recent past, a significant factor explaining India's GHG emissions trajectory increase is the high rate of carbon intensity of the energy system. As rightly identified by the national policy framework, present and future strategies should be heavily focussed on low-carbon growth and within this space, experimenting with conjoint energy and carbon markets could prove to be a game changer.

In spite of the enormous need to focus on renewable energy development in the country, the present share of renewable energy is a miniscule part of the total primary energy supply of the country. The situation improves a little considering that the entire non-commercial biomass is sustainably supplied to the energy system. Recent national policy focus has been encouraging but there are serious gaps that may need to be filled in the renewable energy space. 


\section{Certain Key Energy Demand Sectors Will Play an Important Role in the Energy Transitions}

The Industry, Transport and Commercial sector has witnessed significant increases in energy consumption. This is a manifestation of the change in the structural nature of the Indian economy and rapid urbanisation, a trend which is likely to continue. We may also witness a surge in residential energy consumption, owing partly to increased energy access and energyintensive asset acquisitions such as air conditioners. Identifying the factors responsible for such energy demand transitions within a nuanced understanding of the underlying policy and regulatory landscape, would be crucial to create a new policy framework that helps decouple energy and service demand particularly in the transport sector. We are witnessing good progress in the Industry sector, partly because of a dedicated energy efficiency improvement programme and partly due to demand reduction owing to process improvements.

Table 3: Overview of key carbon-centric interventions in the Indian economy

\begin{tabular}{|c|c|c|}
\hline Theme & Intervention & Features \\
\hline \multirow[t]{7}{*}{$\begin{array}{l}\text { Energy } \\
\text { Efficiency }\end{array}$} & $\begin{array}{l}\text { Energy Conservation } \\
\text { Building Code (ECBC) }\end{array}$ & $\begin{array}{l}\text { Design principles through which new, large commercial } \\
\text { buildings are designed to reduce their energy demand. }\end{array}$ \\
\hline & $\begin{array}{l}\text { National Energy Labelling } \\
\text { Programme }\end{array}$ & $\begin{array}{l}\text { Promotion of enhanced adoption of higher efficiency } \\
\text { appliances by users. }\end{array}$ \\
\hline & $\begin{array}{l}\text { Energy Efficient } \\
\text { Technology for Small \& } \\
\text { Medium Enterprises (SME) } \\
\text { Sector }\end{array}$ & $\begin{array}{l}\text { Upgrading the energy efficiency of } 25 \text { clusters of SMEs } \\
\text { across the country (belonging to high energy industrial sub- } \\
\text { sectors). }\end{array}$ \\
\hline & $\begin{array}{l}\text { Green Rating for } \\
\text { Integrated Habitat } \\
\text { Assessment (GRIHA) }\end{array}$ & $\begin{array}{l}\text { Convergence of various tools and methods reduces } \\
\text { resource consumption, and enhances the use of renewable } \\
\text { and recycled resources by the building sector and } \\
\text { mainstreams sustainable habitat. }\end{array}$ \\
\hline & $\begin{array}{l}\text { Initiatives taken by the } \\
\text { Indian Steel Industry to } \\
\text { implement energy } \\
\text { efficiency measures }\end{array}$ & $\begin{array}{l}\text { Technological improvements in steel production processes } \\
\text { like high top pressure-high blast temperature, pulverised } \\
\text { coal injection; use of modern electric arc furnaces (replaces } \\
\text { steel scrap); installation of energy recovery coke ovens to } \\
\text { meet power requirements as well as to reduce emissions. }\end{array}$ \\
\hline & $\begin{array}{l}\text { Renovation and } \\
\text { Modernisation (R\&M) of } \\
\text { old thermal power } \\
\text { stations }\end{array}$ & $\begin{array}{l}\text { Promotes renovation and modernisation and Life Extension } \\
\text { (LE) of existing old power stations through opportunities to } \\
\text { get additional generation at low costs in short gestation } \\
\text { periods and improved efficiency in terms of environmental } \\
\text { emissions and reliability. }\end{array}$ \\
\hline & $\begin{array}{l}\text { National Mission on Micro } \\
\text { Irrigation }\end{array}$ & $\begin{array}{l}\text { Improvement in energy efficiency through micro irrigation } \\
\text { systems. Enhancing water use efficiency and agricultural } \\
\text { productivity. }\end{array}$ \\
\hline
\end{tabular}


National Mission for
Enhanced Energy
Efficiency (NMEEE)

Integrated Power

Development Scheme

(IPDS)

Smart Cities Mission

Atal Mission for

Rejuvenation and Urban

Transformation (AMRUT)

Information Service on

Energy Efficiency (ISEE)

Bachat Lamp Yojana

[through programmatic

CDM mechanism]

Clean \&

Renewab

le energy
National Bio gas and

Manure Management

Programme (NBMMP)

Accelerated Programme on Energy Recovery from Urban Wastes

Rajiv Gandhi Gramin LPG Vitaran Yojana (RGGLVY)

New and Renewable Energy Policy (2005)

Renewable Purchase Obligations

National Clean Energy Fund (NCEF)

Deen Dayal Upadhyaya

Gram Jyoti Yojana

(DDUGJY)

Energy market reforms
NMEEE was enacted as part of The National Action Plan on Climate Change launching national programmes promoting energy efficiency through financing, market transformation, DSM and energy saving scheme 'Perform, Achieve, and Trade.'

To address the problem of distribution losses by financing the modernisation of sub-transmission and distribution networks.

100 smart cities are planned with the objective to develop new generation cities, which will provide core infrastructure and a clean and sustainable living environment.

A new urban renewable mission launched for 500 cities with a focus on ensuring basic infrastructure services are provided by adopting climate resilient and energy efficient policies.

Dissemination of energy sector related technical and commercial information to producers, manufacturers and service providers.

Promotes energy-efficient lighting through mass distribution of Compact Fluorescent Lamps (CFLs).

Provides clean bio gas fuel to reduce liquefied petroleum gas (LPG) and other conventional fuel usage; climate change mitigation by preventing black carbon and methane emissions; health benefits.

Promotes bio gas-based power generation, especially in the small capacity range (based on the availability of large quantity of animal wastes and wastes from forestry, rural based industries, and kitchen wastes).

Programme adopted under the 'Vision-2015' for the liquefied petroleum gas (LPG) sector focussing on raising the population coverage of LPG in rural areas and areas where coverage is low, to reduce dependence on wood-based fuel resources.

Promotes all forms of renewables to reduce dependency on non-renewables.

Minimum percentage of the total power that electricity distribution companies and large power consumers need to purchase from renewable energy sources and create a market for renewables.

Imposing a cess on coal at a rate of Rs. 200 /tonne of coal in India in order to support clean energy.

Rural electrification programme designed to provide electricity to villages using renewable sources through capital subsidies.

Promote renewable energy production through energy market reforms (using policy/procedures such as Electricity Act 2005, Tariff Policy 2003, Petroleum \& Natural Gas Regulatory Board Act 2006). 


\begin{tabular}{|c|c|c|}
\hline \multirow[t]{5}{*}{$\begin{array}{l}\text { Energy } \\
\text { Conserva } \\
\text { tion and } \\
\text { Security }\end{array}$} & $\begin{array}{l}\text { A National Urban } \\
\text { Transport Policy (NUTP), } \\
2006\end{array}$ & $\begin{array}{l}\text { The primary goal of programmes under this policy is to } \\
\text { ensure easily accessible, safe, affordable, quick, } \\
\text { comfortable, reliable, and sustainable mobility for all } \\
\text { (essentially promoting public transport). }\end{array}$ \\
\hline & $\begin{array}{l}\text { Clean Development } \\
\text { Mechanism-Afforestation } \\
\text { and Reforestation }\end{array}$ & $\begin{array}{l}\text { To achieve net additional carbon serquestration with net } \\
\text { area afforested, C-stock in baseline, MAI of biomass and soil } \\
\text { carbon. }\end{array}$ \\
\hline & National Forest Policy & $\begin{array}{l}\text { Meets fuel, fodder and timber needs of forest dependents } \\
\text { through Joint Forest Management to regulate illegal timber } \\
\text { extraction and therefore deforestation, which in turn will } \\
\text { improve per capita emissions. }\end{array}$ \\
\hline & $\begin{array}{l}\text { National Electricity Policy } \\
\text { [2005] }\end{array}$ & $\begin{array}{l}\text { Stipulates progressive increase in the share of electricity } \\
\text { from non-conventional sources through preferential pricing } \\
\text { for the uptake of green technologies. }\end{array}$ \\
\hline & $\begin{array}{l}\text { Dedicated Freight } \\
\text { Corridors (DFCs) }\end{array}$ & $\begin{array}{l}\text { Two corridors viz. The } 1529 \text { km Mumbai-Delhi and the } 1856 \\
\text { km Ludhiana-Dankuni are being constructed. The project is } \\
\text { expected to reduce emissions by about } 457 \text { million tonne } \\
\text { cO2 over a 30-year period. }\end{array}$ \\
\hline
\end{tabular}

Source: GOI, 2007, 2012, 2013; MoEFCC, 2015; IEA, 2015

\section{Co-benefits and the Energy Access-Development Nexus}

Energy is a critical enabler of development and prosperity. In developing countries, access to affordable and reliable energy services is fundamental to reducing poverty and improving health, increasing productivity, enhancing competitiveness and promoting economic growth. Access to reliable and clean sources of energy is essential for people and the development of societies as a whole as it provides access to clean water, sanitation and healthcare, as well as numerous other benefits such as reliable and efficient lighting, heating, transport and other essential services. While framing national energy policies, we have failed in developing a clearly articulated and evidence-based synergistic co-benefits framework. In the context of limited financial resources, such synergistic frameworks help in prioritising resource allocation and ensure the possibility of aligning multiple markets-a situation that potentially improves efficiency of the economic system.

\section{Energy Efficiency Standards, Including Power Sector Reforms}

The growth of the power sector since independence has been noteworthy. However, the demand for power has been outstripping the growth in availability, and substantial energy peaking and shortages prevail in the country due to inadequacies in generation, transmission and distribution. Very high levels of technical and commercial losses and the lack of a commercial approach in managing utilities has led to unsustainable financial and performance outcomes. Inadequacies in the distribution networks has been one of the major reasons for the poor quality of supply, incorporating significant losses in transit. The widely distributed and rapidly increasing electricity demand network of the country will have to be serviced adequately and in the most efficient manner. We will have to collectively respond to the challenges that the electricity sector imposes on us, particularly in the spirit of achieving 
the broader objectives of the Electricity Act, the National Energy Frameworks and Policies. Most of these challenges are related to improving the technical and financial performance of power utilities, broadly in the context of energy efficiencies through different processes and segments of the power utility value chain.

\section{Governance and Institutional Arrangements}

Responsibilities for policy making and implementation in the energy sector are split between five different ministries and several government commissions and agencies. The policy and implementation landscape gets further complicated when state and central governments share responsibilities and roles. The development and administration of energy policy lies with various ministries and departments and therefore, synergistic reforms are essential to wider sector gains. For example, reforms in the electricity and the coal sector have not been synergistic, which has partly been a centre-state jurisdictional problem. In addition, there are serious dissonances in the governance/institutional framework of the power sector. For example, the Ministry of Power is concerned with long-term power sector planning, policy formulation, assigning investment priorities, monitoring the implementation of legislation with regards to thermal and hydropower generation, transmission and distribution. It liaises within the central government, with the State Electricity Boards and the private sector. The Bureau of Energy Efficiency (BEE) is a statutory body under the Ministry of Power, set up under the Energy Conservation Law 2001 to co-ordinate energy efficiency and conservation policies and programmes. The Central Electricity Regulatory Commission (CERC) is responsible for regulating all activities related to power at the central and interstate level. Its responsibilities include managing electricity trading, regulating interstate transmission and tariffs, generating the tariffs of central utilities and regulating transmission lines. State Electricity Regulatory Commissions (SERCs) deal with licensing, tariffs and competitive issues within each state. With rapid urbanisation and cities emerging as the dominant electricity consuming centres, the possibility of re-visiting the 74th Constitutional Amendment and including electricity generation and distribution within the ambit of the city governments is a prospect. This may be vital for securing the desirable synergistic climate-energy transitions.

\section{A Framework to Effectively Transition to Sustainable Energy}

The Indian energy sector offers certain key challenges, which could potentially be important opportunities. These are summarised below.

\section{Energy Security}

1. Augmentation of domestic production of coal, oil, gas and other energy sources;

2. A stable and attractive policy regime to ensure substantial private investment, including foreign investment in oil and natural gas blocks, and new capacities for renewable energy;

3. Investments in energy assets in foreign countries, especially for coal, oil and gas, and uranium to be stepped up; 
4. To meet any possible disruption in oil supplies, adequate storage capacities and fuel substitution strategies need to be created.

\section{Long and Short Term Challenges}

1. To address the growing gap between the demand and supply of energy and environmental externalities associated with energy use, particularly in the context of long-term environmental changes like climate change;

2. Integrated macro-economic energy and environment paths need to be established, which clearly addresses issues related to investment requirements and their availability, energy supply, technology, R\&D and transfer issues, local and global environmental implications and institutional innovations/requirements;

3. Environmental impact of various energy generating options is also a growing concern. The challenge therefore will be to ensure optimal exploitation of available fossil energy resources, use of enhanced recovery techniques and shift focus towards renewable resources.

\section{Renewable Energy and its Wider Development and Deployment}

1. Some of the barriers that will need priority action are: creating transmission infrastructure to evacuate renewable energy power from remote locations, making available low-cost funds (particularly for off-grid applications), creating sustainable business models for de-centralised renewable energy projects, and promoting linked rural entrepreneurship and distributed service companies/employment/skill markets;

2. Rapid up-scaling of off-grid programmes in an inclusive mode with the option of tinkering with policy frameworks that could potentially generate better outcomes;

3. Concerns regarding the pace of technology development, land availability and transfer of new technologies need to be mitigated;

4. Clean energy generating options such as wind, nuclear and hydro have a high potential to address growing energy scarcity and emissions but face a number of socioenvironmental issues such as dam construction, flooding of areas, damage to the ecological system, and resettlement and rehabilitation of the affected population. We need to work towards evolving a balanced development model, which does not preclude us from using a possible renewable source that may be cost-effective and have significant environmental benefits.

\section{Cities and Energy: An Indian Perspective}

Existing cities and cities in the making will play a significant role in defining energy demand and consumption profiles. The current urbanisation trends indicate an intensification of energy consumption in urban centres, partly due to the concentration of commercial and industrial activities, but more so because of the demographic transitions and income growth. It is reasonable to assume that cities are and will play an important role in triggering energy transitions that are in line with national and regional objectives. India's energy future and transitions will be primarily defined by how cities decide to acquire, transmit and use energy 
and electricity, linked with enabling policies and instruments. A related question is with regards to climate mitigation, where cities are the principal players in ensuring that the globally agreed climate mitigation goals are met and bottom-up Intended National Determined Contributions (INDCS) are implemented. While understanding the enormity of challenges at the interface of cities and energy, it is important to understand that cities in India do not wield significant influence on the energy sector but paradoxically are the most important sites where targets within Goal 7 of the SDG would be achieved. The following are some issues that may require serious consideration in the coming years to help resolve the energy puzzle: 


\section{Pricing and Governance}

India's governance structure does not explicitly allow city level administration (as defined in the $74^{\text {th }}$ Constitutional Amendment Act) to take decisions on issues related to energy such as production and distribution of electricity, policies on fuel use, and energy/electricity prices. Cities can only control the flow of energy, to some extent, but lack jurisdictional powers to define choices over its form. It also is subservient to policies that are finalised at the state level, with no control over defining its scope, structure and instruments. Pricing and governance questions could be important in the context of improving universal access and thereafter, ensuring quality and reliability of energy supply. While city governments have a poor record with utility pricing in terms of following marginal cost principles, reforming the landscape would be most critical to ensure universal coverage.

\section{Urban Planning}

Indian cities are witnessing an explosion in energy demand in the transportation sector, partly because of poor planning that leads to higher trip lengths. In addition, the lack of an effective public transport system leads to more and more people shifting towards private vehicles. The important issue to be considered here is with regards to fuel-switch towards either gas-based motive power or more aggressively, towards electric vehicles both private and in public transport systems. It is assumed that electricity in this case, will be generated from renewable sources. Cities can play an effective role in ensuring that appropriate electric-charging infrastructure is available and appropriate policies are implemented that promote development and large-scale deployment of decentralised or centralised renewable energy systems that are linked to mini-grids connecting itself to the transport and electric charging infrastructure.

So far, the Government of India has not been entirely successful in implementing fuel efficiency standards in automobiles, and is currently enacting policies to accelerate the deployment of hybrid and electric vehicles ${ }^{4}$. Cities can lead the way by having the right kind of infrastructure in play.

\section{Building Codes for Cities}

As mentioned in India's INDC to the UNFCCC, its biggest challenge will be to build the infrastructure to support a growing urban population which is expected to rise by another 10 per cent by 2030. This urbanisation process will raise the demand for infrastructure (housing, roads) and all other essential services that come with it. It will also intensify the demand for building materials such as cement and steel. India has been fairly successful with the existing building codes but a new paradigm needs to evolve that reconciles the concept of embodied energy and provides a policy architecture that incentivises a shift towards low-energy building material. By enforcing uncompromising building, construction and maintenance codes for the 
yet-to -be -built infrastructure particularly in the small and medium towns, the country can avoid energy lock-in.

\section{Lighting, Heating and Cooling Energy Demand}

Similar to building codes, energy appliances and their efficiencies will play a large role in reducing overall energy demand. Such measures have met with success across regions and cities around the country. While we have witnessed good results in the lighting technology and demand segment due to the appliance standards programme in India the heating/cooling demands are still high and non-standardised. We may have to re-think building design codes that could help us utilise the environmental and ambient conditions in setting up building systems, which in turn ensure that we reduce our heating/cooling demand in the building sector.

\section{Electricity Quality and Supply}

Due to the existing infrastructure bottlenecks in the supply and distribution of electricity through the electricity grid, the Power Ministry has proposed a $\$ 50$ billion programme to upgrade the efficiency and capacity of the Indian electricity grid, according to a report on India's electric-sector transformation (Buckley, 2015). The critical strategy here is to slash the high technical, commercial and non-technical losses (theft), which is stated by government sources to be at 25 per cent but in reality is much higher around 40-50 per cent. Through electricity grid infrastructure improvement and focus on reducing energy losses, electricity can be delivered with increasing efficiency while reducing the demand for primary fuel production in the process. This may potentially unlock huge amounts of energy that may be used to fill the access gap.

\section{Energy producers: Combining State and Decentralised Production}

The continuous power blackouts in most of the northern and eastern regions of the country create a compelling logic of combing decentralised electricity generation with the centralised system. This could help judiciously allocate scarce financial resources and ensure that the infrastructure is running at a reasonable capacity. Such measures could save hundreds of billions of dollars in capital investment, reduce power costs by up to 40 per cent, reduce vulnerabilities, safeguard the integrity of fragile ecosystems, and improve energy access.

\section{Decentralisation of the Electricity Grid}

Most of the current discourse at city level energy planning is on how to integrate decentralised energy systems with the existing electricity grid through smart grid infrastructure. By having market reforms and incentivised tariffs, cities can play a major role in making this transition. Having attractive schemes in place to drive electricity boards and consumers to adopt such integrated renewable technology systems have proven successful in developed countries and will soon need to be considered in the Indian context.

\section{Fuel Strategies: Is Gas a Viable Alternative for Transport?}

Even though natural gas production in India in significantly higher than oil, the deployment of these sources is an issue across different sectors such as transport, domestic fuel use and fertiliser production. It may be an important consideration to think about compressed gas as 
a dominant fuel in the transport sector, driven more so from the issues of lesser social costs. How could cities play an important role in triggering this transition is an important question to be probed.

As a consolidated strategy, we would like to offer four possibilities that could be useful while re-framing the energy sector or to develop a possible pathway, going forward.

1. Recognising that there are 'three connected stories', how are we going to finance the energy/climate mitigation transition, while also achieving targets that we have set for ourselves within the SDG framework and responding to the global climate agreement? There has to be some amount of convergence within these aspects, which may be different for different contexts but has to be developed, articulated and understood. This is important because we have collectively not succeeded in reconciling economic growth with inequality reduction and environmental improvements.

2. At the core of the climate challenge is the energy challenge and we need to recognise this aspect, which gives us an opportunity to re-frame the entry point. This may be vital to gain political and financial traction/acceptance. We also need to understand that a complete overhaul of the energy/climate system in its synergistic framework will not be possible without political consensus and therefore, the way domestic political frameworks will emerge/engage will partly define the energy/climate future. This is recognisable in the context of the energy/climate system being deeply inter-connected systems, and overhauling such a system in incremental steps would not yield useful gains. This is more valid in the context of technological uncertainties and a need for massive energy co-operation across powerful vested interests and therefore, the importance of political processes and frameworks.

3. Shifting to a low carbon system will require considerable planning, long lead times, dedicated financing and coordinated action across many parts of the economyproducers, consumers, distributors-and this has to be clearly laid down with zero ambiguities. We must recognise that a low-carbon system provides three beneficial outcomes: better environment, cost-effective energy access and re-defines the way the economy will function.

4. Finally, we need to work towards developing clearly laid down pathways of energy development. These pathways should initially focus on low-hanging fruit like improving energy efficiency and later on, shift towards large scale low carbon electricity, fuel switch in the auto sector and district cooling/heating. These pathways should be recognisable in the context of energy access and climate goals. 


\section{References}

Buckley, T. (2015). India's electricity-sector transformation. Institute for Energy Economics and Financial Analysis. Retrieved on 7 November 2016, from http://ieefa.org/wpcontent/uploads/2015/08/IEEFA-Indian-Electricity-Sector-Transformation-11-August2015.pdf

Government of India (GOI). (2006). Integrated Energy Policy. Planning Commission, Government of India. Retrieved on 7 November 2016, from http://planningcommission.nic.in/reports/genrep/rep_intengy.pdf

GOI. (2007). Eleventh Five Year Plan (2007-2012), Volume 1: Inclusive Growth. Planning Commission, Government of India. Retrieved on 7 November 2016, from http://planningcommission.nic.in/plans/planrel/fiveyr/11th/11_v1/11th_vol1.pdf

GOI. (2012). India Second National Communication to the United Nations Framework Convention on Climate Change. Retrieved on 7 November 2016, from http://unfccc.int/resource/docs/natc/indnc2.pdf

GOI. (2013). Twelfth Five Year Plan (2012-2017): Faster, More Inclusive and Sustainable Growth, Volume I. Planning Commission, Government of India. Retrieved on 7 November 2016, from http://planningcommission.gov.in/plans/planrel/12thplan/pdf/12fyp_vol1.pdf

International Energy Agency (IEA). (2015). India Energy Outlook. World Energy Outlook Special Report. Retrieved on 7 November 2016, from http://doi.org/https://www.iea.org/publications/freepublications/publication/africaenergy-outlook.html

Ministry of Environment, Forest and Climate Change (MoEFCC). (2015). India: First Biennial Update Report to the United Nations Framework Convention on Climate Change. MoEFCC, Government of India. Retrieved on 7 November 2016, from http://doi.org/10.1017/CBO9781107415324.004

United Nations (UN). (2015). Transforming our world: The 2030 agenda for sustainable development. Retrieved on 7 November 2016, from https://sustainabledevelopment.un.org/content/documents/7891Transforming\%200ur\% 20World.Pdf 



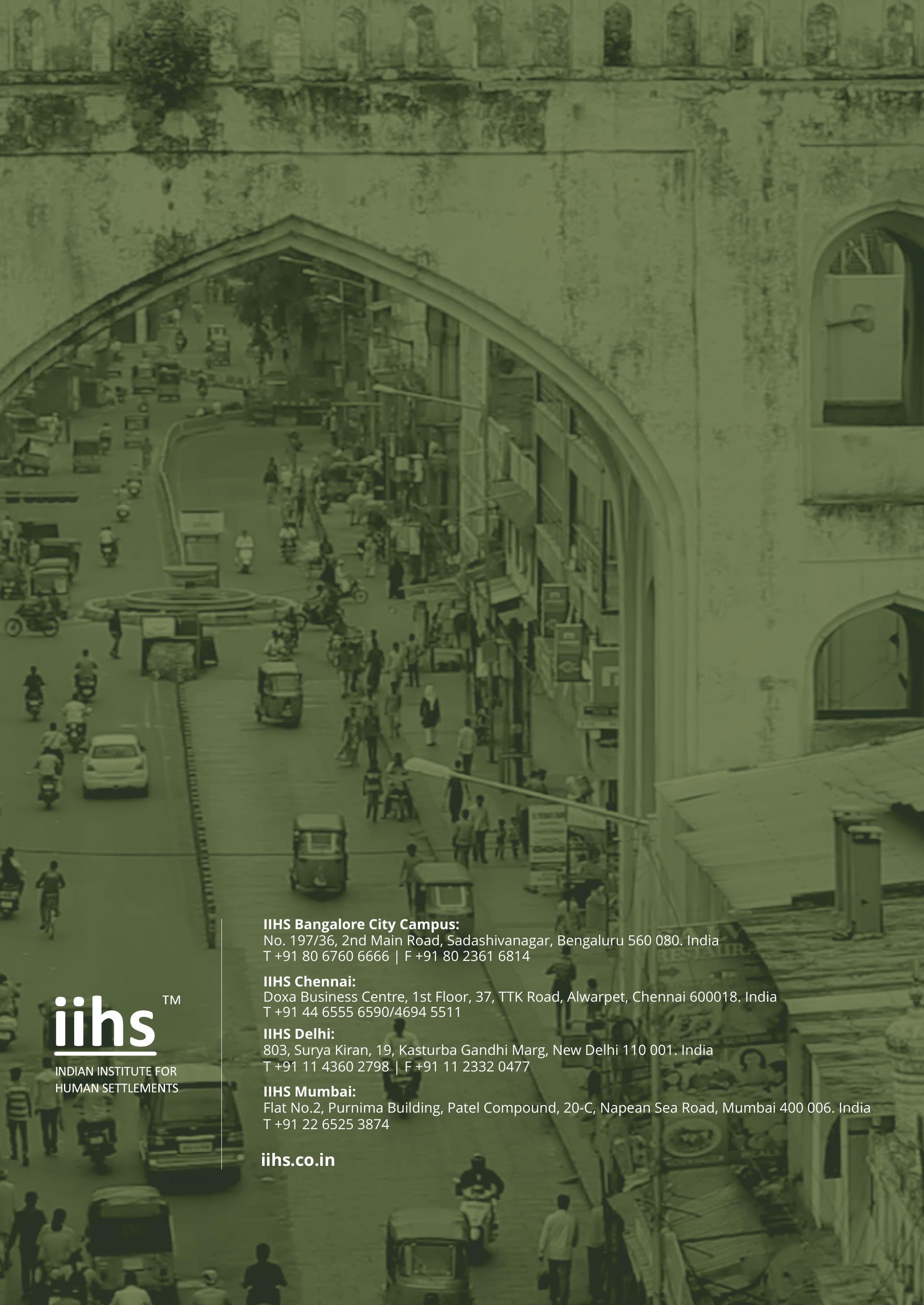

